\title{
The Effect of Interactivity, Cost Effectiveness, and Compatibility on the Use of Social Media and its Implications for Organizational Performance
}

\author{
B Medina Nilasari, Farida Jasfar, Agustinus Sri Wahyudi \\ medina@trisakti.ac.id
}

\begin{abstract}
The purpose of this research is to examine the influence of interactivity, cost effectiveness, compatibility through social media usage and the implications toward organizational performance. Analytical technique used in testing the hypothesis is by Structural Equation Model (SEM) method. The respondent in this research were 220 manager, from 14 Hotels of Indonesian stated-owned enterpriseslocated in the islands of Bali, Java and Sumatra. The result showed that interactivity, cost effectiveness, and compatibility significantly influence social media usage, and the social media usage has a significant effect on organizational performance and entrepreneurial orientation. The result also showed that entrepreneurial orientation as mediating variable between social media usage and organizational performance.
\end{abstract}

Keywords: Interactivity, Cost Effectiveness, Compatibility, Social Media Usage, Entrepreneurial Orientation, Organizational Performance

\section{INTRODUCTION}

In the digital era, this has brought changes to the hospitality industry. Many uses of social media for hotel marketing, which is one example of changes that occur due to technology. In fact, today almost everyone depends on the technology itself. This has become a promising potential for using social media for hotel marketing. There is no need to spend large funds to advertise on television or magazines, to market products through social media.

Indonesia ranks 4 th and Jakarta ranks 3rd for the most active Facebook user in the world. This shows the magnitude of the potential that can be used to develop new opportunities or simply to be able to survive in competitive competition. The use of social media can change the style of communication more interactively and participatively, this results in the relationship between the company and its consumers becoming more intense, more personal and equal (horizontal). The use of social media makes consumers can comment directly about what is being done even what is happening with the company. A company can communicate with its customers more easily and closely, by only creating one account or fanpages on social media (Facebook or Twitter).

Many companies use social media to: 1) connect with their customers; 2) listen to the main stakeholders; 3 ) providing customer service; 4) developing valuable content for consumers; 5) involving consumers in product formulation and development (Pride, Hudges\&Kapoor, 2017). Although the popularity of social media is a recent phenomenon, many businesses have used it to achieve its goals, whether it for long-term such as awareness and brand reputation, or short-term goals such as generating sales (Pride et. al., 2017).

According to the results of the research by Odoom, Dorson, and Acheampong (2017), the use of social media is positively influenced by 3 (three) factors, namely: interactivity, cost effectiveness, and compatibility. The research was conducted in Ghana. This is in line with research conducted in Malaysia by Ainin, Parveen, Moghavvemi, Jaafar, and Shuib (2015) which prove that interactivity, cost effectiveness, and compatibility have a positive effect on Facebook, while trusts have no effect. 
The Effect of Interactivity, Cost Effectiveness, and Compatibility on the Use of Social Media and its Implications for Organizational Performance

Social media facilitates two-way communication between customers and organizations. Organizations that utilize the latest social media technology seem to outperform their competitors and report benefits such as lower costs and better efficiency (Harris and Rea, 2009). It is therefore important to investigate the specific impact of social media on organizational performance (Parveen, Jaafar, and Ainin, 2016). Research conducted by Parveenet. al. (2016) in Malaysia found that the use of social media has a strong positive impact on organizational performance in 3 (three) aspects, namely: 1). reduce costs (cost reduction); 2). improve customer relations (improved customer relations); 3). improve information accessibility (enhanced information accessibility).

Social media also positively influences entrepreneurial orientation, according to Parveenet. al. (2016). Entrepreneurial orientation is the methods, practices and decision-making styles that managers use to act in entrepreneurship. This includes processes such as: 1). experiment with promising new technologies; 2). willing to take advantage of new product market opportunities; 3 ). has a tendency to do business at risk (Lumpkin and Dess, 1996). According to Parveenet. al. (2016), the effect of using technology or social media on organizational entrepreneurial orientation is rarely studied.

Entrepreneurial orientation refers to the company's strategic orientation, capturing the appreciation of visionary entrepreneurs for the style, methods and practices of decision makers (Lumpkin and Dess, 1996). The results of previous research from Wang, Thornhill, and De Castro (2017) prove that new businesses with entrepreneurial orientation such as innovative, proactive, and risk decision makers achieving superior performance. The results of the study of Wiklund and Shepherd (2003) have proven that entrepreneurial orientation has a positive effect on company performance.

\section{THEORETICAL FRAMEWORK AND HYPOTHESIS}

Organizational performance or organization performance is the goal of running a company. Therefore the success of a company can be seen from its performance. Performance measurement is a measurement of the results of the implementation of the strategy, if it is considered good it will be used as a measure for the performance of the next period. If the indicator used as a measure of performance increases, the strategy has been well implemented (Anthony and Govindarajan, 2001). Gray, Matear, and Matheson (2002) argue that performance can be divided into 3 (three) measures, namely: measured by business performance (market share, profit, company sales growth compared to competitors), marketing performance (customer satisfaction and loyalty and brand awareness) company against competitors), and other performance measures (Return on Investment and total sales).

Entrepreneurial orientation is an important asset for companies in competing in the electronic environment (Colton et. al., 2010). Entrepreneurial orientation is the decision-making practice, managerial philosophy, and strategic behavior that is entrepreneurial, with entrepreneurship referring to 3 (three) components, namely: innovation, proactivity, and risk taking (Anderson, Covin, and Slevin, 2009). So that entrepreneurial orientation can be said to be an intangible asset of an organization that allows companies to gain and maintain their competitive advantage, which is useful for achieving superior organizational performance. This refers to the theory of Resources Base View (RBV).

The definition of interactivity according to Liu and Shrum (2002) is the extent to which two or more communication parties can act on each other, on the communication media, and on the message, and the extent to which the influence is synchronized. Ha and James (1998) describe interactivity to embrace the ability of users to provide content in response to sources of communication partners. Thus interactivity is characterized as two-way communication between the company and/or among customers (Goldfarb and Tucker, 2011). Sundar, Kalyanaraman, and Brown (2003) conceptualize two main classifications of interactivity: Functional interactivity, which consists of features found on social sites that allow users to interact in several modes; 
The Effect of Interactivity, Cost Effectiveness, and Compatibility on the Use of Social Media and its Implications for Organizational Performance

Contingency interactivity, which occurs when user roles can be exchanged and actors respect each other. For example on Facebook and Twitter, which allows contextual interactivity among the public by offering a type of communication relationships that are often lacking from websites (Saffer, Sommerfeldt, and Taylor, 2013).

Experts have recommended social media as a cost-effective and efficient platform, available for marketers (Ainin et. al., 2015). In addition to a relatively cheaper platform, social media enables sharing of collaborative content to people who are geographically dispersed, effectively (Korda and Itani, 2013). The cost of reaching customers spread geographically will be higher through traditional media. Hoffman and Fodor (2010) also stated that adopting social media would result in significant cost savings. However, social media is a costeffective technology, and organizations can communicate directly with their customers at relatively low costs (Kaplan and Haenlein, 2010).

Compatibility is the extent to which innovation is in accordance with the values that exist today in the organization, and current needs (Rogers, 1995). Compatibility has been considered an important factor for adoption of innovation (Wang et. al., 2010). When technology is compatible with work application systems, companies will tend to consider adopting the new technology (Ainin et. al., 2015). There is a lot of literature on how the compatibility between technologies influences competition between companies, and what currently exists shows that users in the market prefer to use technology with a wide range of areas (unlimited) (Immorlica, 2007).

Various definitions of social media exist today, because social media is still growing and constantly changing. According to Pride et. al. (2017), social media is about people, about culture and participation, which means that people can now discuss, vote, connect and advocate much easier than before. According to Parveenet. al. (2016), social media has changed the way business is done. This enables open communication that helps organizations understand customer needs and also motivates organizations to proactively respond to customer needs. According to Samuel (2017), advertising through social media presents two distinct advantages: (1). Consumers are not always aware that they are advertised and can receive advertisements more easily; (2). The basis of social media advertising is concise, and very targeted, unlike traditional advertising.

Based on the theory and results of previous studies, this study will examine the factors that influence social media usage, and how the influence of the use of social media usage on organizational performance, which is mediated by the Entrepreneurial orientation.

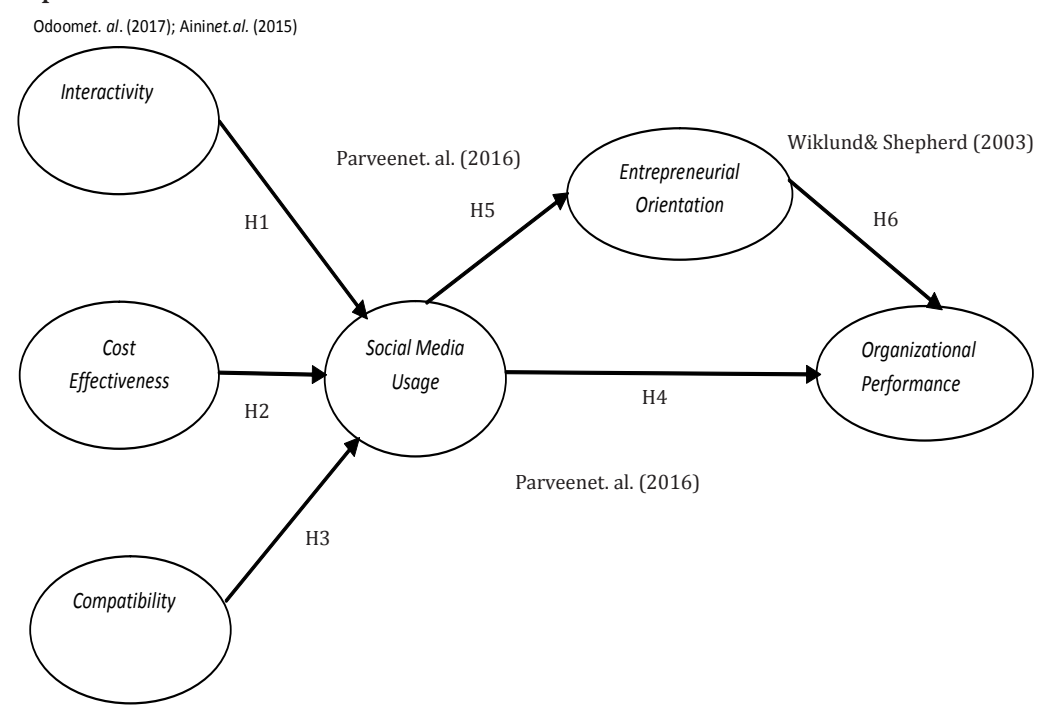

Fig1. Conceptual Framework 
The Effect of Interactivity, Cost Effectiveness, and Compatibility on the Use of Social Media and its Implications for Organizational Performance

Odoom et al. (2017) found a positive influence between interactivity and the use of social media. This is in line with the results of Ainin et al. (2015), that interactivity has a positive effect on Facebook usage. Facebook and Twitter, for example, enable interacting between the public contingency by offering a type of building communication relationships that are often lacking from websites (Saffer et. al., 2013). Cone (2008) states that having a social media presence is not enough for the organization. It is said that this must be complemented by customer interactions. Lovejoy et al. (2012), shows that interactive features such as 'like' and 'mention'replies allow organizations to communicate with their customers. Interactiveity eventually bridges the gap created by differences in time and geographical location (Michaelidou et. al., 2011) to be the main consideration for adopting social media. Considering this, the first hypothesis for this study is as follows:

H1: Interactivity positively influences social media usage.

This research previously highlighted the importance of costs in the adoption and use of technology and found a direct and significant relationship between costs and technology adoption (Alam and Noor, 2009). Studies have found cost effectiveness to be an important variable in the application of new technologies (Chong and Chan, 2012). Social media is suitable for SMEs (Small and Medium Enterprises) because of low costs, low barriers to participation and low utilization of information technology needed to use it (Derham, Cragg, and Morrish, 2011). Historically, marketing spent on delivering messages was often through cash and was generally seen as a big expense (Weinberg and Pehlivan, 2011). Experts have recommended social media as an effective and efficient platform available for marketers (Ainin et. al., 2015). Research from Odoomet. al. (2017) found a positive influence between cost effectiveness and the use of social media. Likewise with the results of Aininet. al. research. al. (2015), that cost effectiveness has a positive effect on Facebook usage. Considering this, the second hypothesis for this study is as follows:

H2: Cost effectiveness positively influences social media usage.

Findings from empirical studies assessing compatibility constructs in new technologies have presented positive and negative results. Ramdani, Kawalek\& Lorenzo (2009) for example, found compatibility to be an insignificant factor in the adoption of company systems. In the same case Low, Chen \& Wu (2011) also found the impact of not significant compatibility in the application of cloud computing. Whereas on the contrary Hsu, Lu, and Hsu (2001) found a significant effect of compatibility in adopting MMS in a group of potential MMS users and indicated that they would adopt MMS if they felt that using MMS was in accordance with their values and beliefs. Likewise in the study of Odoomet. al. (2017), found a positive influence between compatibility and use of social media. This is in line with the results of Aininet. al. (2015), that compatibility has a positive effect on Facebook usage. Incorporating social media in business will be the most appropriate concept because it helps to effectively describe target customers and businesses will be able to spread the content of their products and services in an instant (Derham et al., 2011). Because many findings show inconclusive results, it is interesting to study the influence of compatibility on the use of social media. Considering this, the third hypothesis for this study is as follows:

H3: Compatibility positively influences social media usage.

Shuai and Wu (2011) found a positive relationship between the use of technology and organizational performance. This is in line with the results of Odoomet. al. (2017) who found that interactivity, cost effectiveness, and compatibility were very important factors for the use of social media, which led to the realization of some performance for SMEs. The results of his research show that there is a positive influence on the use of social media on the performance of SMEs. Whereas Parveenet. al. (2016), found that the use of social media has a strong positive impact on organizational performance in 3 (three) aspects, namely: reducing costs (increasing customer relations), and increasing information accessibility (enhanced information accessibility). Considering this, the fourth hypothesis for this study is as follows:

H4: Social media usage positively influences organizational performance.

American Research Journal of Business and Management Page 4 
The Effect of Interactivity, Cost Effectiveness, and Compatibility on the Use of Social Media and its Implications for Organizational Performance

Previous research from Parveenet. al. (2016) shows that the use of social media has a positive effect on entrepreneurial orientation. Likewise with Elliot and Boshoff (2005), found a significant relationship between entrepreneurial orientation and perceived success of internet marketing (perceived success of internet marketing). Mostafa et. al., (2006) also found that organizations with a high entrepreneurial orientation were more committed to the internet, and had higher performance compared to organizations with a low entrepreneurial orientation. Considering this, the fifth hypothesis for this study is as follows:

H5: Social media usage positively influences entrepreneurial orientation.

Wang et. al. (2017) show that the influence of entrepreneurial orientation on company performance is more positive in new businesses that make cognitive, regulator, and normative efforts than those who do not do this legitimacy. Entrepreneurial scholars have attempted to explain performance by investigating entrepreneurial orientation of a company (firm marketing orientation/entrepreneurial orientation). Entrepreneurial orientation refers to the company's strategic orientation, capturing the appreciation of visionary entrepreneurs for the style, methods and practices of decision making (Lumpkin and Dess, 1996). Given the importance of entrepreneurship to company performance (McGrath et. al., 1996), entrepreneurial orientation can be an important measure of how companies organize. In line with the results of the study of Wiklund and Shepherd (2003) which prove that entrepreneurial orientation has a positive effect on company performance. Considering this, the sixth hypothesis for this study is as follows:

H6: Entrepreneurial orientation positively influences organizational performance.

\section{METHODS}

This study aims to test hypotheses (hypothesis testing). In this study the research variables tested were exogenous variables (independent variables), namely interactivity, cost effectiveness, and compatibility. Then endogenous variables (dependent variables) are social media usage and organizational performance, whereas entrepreneurial orientation is a mediating variable (meditating variable).

Table1. Variable Indicator

\begin{tabular}{|c|c|c|c|}
\hline Variable & Dimension & Indicator & Sources \\
\hline Interactivity (x1) & & $\begin{array}{l}\text { 1. Our social media platform offers interactive } \\
\text { communication with customers. } \\
\text { 2. Offers interactive mechanism for value co- } \\
\text { creation with our audience. } \\
\text { 3. Ability to engage customers via mentions and } \\
\text { replies with controlled message contents. }\end{array}$ & Odoomet. al., 2016 \\
\hline $\begin{array}{c}\text { Cost effectiveness } \\
(\mathrm{x} 2)\end{array}$ & & $\begin{array}{l}\text { 1. We use social media to cut down cost on } \\
\text { marketing communications. } \\
\text { 2. Our social media platform saves costs } \\
\text { relating to time and effort in marketing, } \\
\text { branding, and customer service. } \\
\text { 3. Social media is more effective to us than } \\
\text { traditional media. }\end{array}$ & Odoomet. al., 2016 \\
\hline $\begin{array}{c}\text { Compatibility } \\
(\mathrm{x} 3)\end{array}$ & & $\begin{array}{l}\text { 1. The chosen social media is compatible with } \\
\text { with our existing IT infrastructure. } \\
\text { 2. Social media is compatible with our business } \\
\text { process and operations. } \\
\text { 3. It is easy to integrate social media with our } \\
\text { existing departmental strategies. }\end{array}$ & Odoomet. al., 2016 \\
\hline
\end{tabular}


The Effect of Interactivity, Cost Effectiveness, and Compatibility on the Use of Social Media and its Implications for Organizational Performance

\begin{tabular}{|c|c|c|c|}
\hline \multirow{3}{*}{$\begin{array}{c}\text { Social Media } \\
\text { Usage(y1) }\end{array}$} & $\begin{array}{l}\text { 1. SM for } \\
\text { Marketing }\end{array}$ & $\begin{array}{l}\text { 1. Advertise and promote product and services. } \\
\text { 2. Conduct marketing research. } \\
\text { 3. Get referrals (word of mouth via likes, shares, } \\
\text { and followers). }\end{array}$ & \multirow{3}{*}{$\begin{array}{c}\text { Parveenet. } \\
\text { al., 2016; } \\
\text { Papastathopoulou } \\
\text { \& Avlonis, 2009; } \\
\text { Moen et. al., 2008; } \\
\text { Elliot \& Boshoff, } \\
\text { 2005; Teo\& Choo, } \\
\text { 2001. }\end{array}$} \\
\hline & $\begin{array}{l}\text { 2. SM for } \\
\text { Customer } \\
\text { Relations and } \\
\text { Services }\end{array}$ & $\begin{array}{l}\text { 1. Communicate with customers. } \\
\text { 2. Receive customer feedback on existing \& new } \\
\text { product/services. } \\
\text { 3. Reach new customers. }\end{array}$ & \\
\hline & $\begin{array}{l}\text { 3. SM for } \\
\text { Information } \\
\text { Accessibility }\end{array}$ & $\begin{array}{l}\text { 1. Search for general information. } \\
\text { 2. Search for competitor information. } \\
\text { 3. Search for customer information }\end{array}$ & \\
\hline \multirow{3}{*}{$\begin{array}{l}\text { Entrepreneurial } \\
\text { Orientation (y2) }\end{array}$} & 1. Proactiveness & $\begin{array}{l}\text { 1. Actively take actions to elicit the responses } \\
\text { from the competitors. } \\
\text { 2. Have strong ambitions to take the lead of the } \\
\text { competitors. } \\
\text { 3. Always invests more resources than the major } \\
\text { competitors in forecasting and exploiting. }\end{array}$ & \multirow{3}{*}{$\begin{array}{l}\text { Parveenet. al., } \\
\text { 2016; Lin et. al., } \\
\quad 2008\end{array}$} \\
\hline & 2. Risk Taking & $\begin{array}{l}\text { 1. To seek the sales growth, our organization is } \\
\text { willing to execute some risky projects. } \\
\text { 2. Even though the cost for some projects } \\
\text { are high, under some conditions, our } \\
\text { organization will still launch those projects. } \\
\text { 3. Our organization can accept the } \\
\text { uncertainties existing in the projects. }\end{array}$ & \\
\hline & 3. Innovativeness & $\begin{array}{l}\text { 1. Our organization frequently tries out new ides. } \\
\text { 2. Our organization seek out new ways to do } \\
\text { things. } \\
\text { 3. Our organization often the first to do } \\
\text { marketing for new products and servoces. }\end{array}$ & \\
\hline \multirow{3}{*}{$\begin{array}{l}\text { Organizational } \\
\text { Performances } \\
\text { (y3) }\end{array}$} & $\begin{array}{l}\text { 1. Impact on Cost } \\
\text { Reduction }\end{array}$ & $\begin{array}{l}\text { 1. Reduced the cost of communication with } \\
\text { customers. } \\
\text { 2. Reduced the cost of advertising and } \\
\text { promotion. } \\
\text { 3. Reduced the cost of customer service and } \\
\text { support. }\end{array}$ & \multirow{3}{*}{$\begin{array}{l}\text { Parveenet. al., } \\
\text { 2016; Molla \& } \\
\text { Heeks, 2007; } \\
\text { Apigian et al., } \\
\text { 2005; Elliot \& } \\
\text { Boshoff, 2005; Teo } \\
\text { \& Choo, 2001. }\end{array}$} \\
\hline & $\begin{array}{c}\text { 2. Improved } \\
\text { Customer Relation } \\
\text { and Services } \\
\end{array}$ & $\begin{array}{l}\text { 1. } \\
\text { 2. Inhanced customer service. } \\
\text { 3. } \\
\text { Improved customer loyalty and retention. }\end{array}$ & \\
\hline & $\begin{array}{l}\text { 3. Enhanced } \\
\text { Information } \\
\text { Accessibility }\end{array}$ & $\begin{array}{l}\text { 1. Enabled easier access to competitor } \\
\text { information. } \\
\text { 2. Enabled easier access to market information. } \\
\text { 3. Enabled faster delivery of information to } \\
\text { customer. }\end{array}$ & \\
\hline
\end{tabular}

Furthermore, respondents were asked to respond to the statements above based on 5 Likert scales $(1=$ strongly disagree to 5 = strongly agree). 
The Effect of Interactivity, Cost Effectiveness, and Compatibility on the Use of Social Media and its Implications for Organizational Performance

Table2. Number of Respondents

\begin{tabular}{|l|l|l|l|}
\hline No. & Hotel & Lokasi & Responden \\
\hline 1. & Inaya Putra Bali***** & Nusa Dua, Bali & 25 \\
\hline 2. & Grand Inna Kuta**** & Kuta, Bali & 19 \\
\hline 3. & Inna Bali Heritage*** & Denpasar, Bali & 7 \\
\hline 4. & Grand Inna Bali Beach**** & Sanur, Bali & 74 \\
\hline 5. & Inna Sindhu Beach Hotel \& Resort ${ }^{* * *}$ & Sanur, Bali & 5 \\
\hline 6. & Inna Bali Beach Resort*** & Sanur, Bali & 24 \\
\hline 7. & Inna Bali Beach Garden*** & Sanur, Bali & 5 \\
\hline 8. & Grand Inna Malioboro**** & Yogyakarta, Central Java & 9 \\
\hline 9. & Grand Inna Samudera Beach*** & PelabuhanRatu, West Java & 5 \\
\hline 10. & Grand Inna Tunjungan $* * * *$ & Surabaya, West Java & 12 \\
\hline 11. & Inna Tretes Hotel \& Resort*** & Pasuruan, East Java & 17 \\
\hline 12. & Grand Inna Medan**** & Medan, North Sumatra & 5 \\
\hline 13. & Grand Inna Padang**** & Muara - Padang,West Sumatra & 6 \\
\hline 14. & Inna Prapat Hotel \& Resort & 7 \\
\hline & & Danau Toba, North Sumatra & 7 \\
\hline
\end{tabular}

Source: Data Collection Results via Google Form (2018)

Based on the table above the sample size of this study is 220 people. This means that it meets the criteria of Hair, Anderson, and Black (2013) that the number of indicators ( 40 indicators) multiplied by $5=200$ samples.

In this study the preliminary test (pre-test) was carried out first to measure validity and reliability. Validity tests are used to measure the validity or validity of a questionnaire. For pre-test with sample 71, the loading factor must reach 0.65 . As for the actual study with 220 respondents, the factor loading limit must reach 0.40 (Hair et al., 2013).

Table3. Validity Test Results

\begin{tabular}{|c|c|c|c|c|c|}
\hline \multirow{2}{*}{ Variable } & \multirow{2}{*}{ Dimension } & \multirow{2}{*}{ Indicator } & \multicolumn{2}{|c|}{ Factor Loading } & \multirow{2}{*}{ Decision } \\
\hline & & & Pre-test & Actual & \\
\hline \multirow{10}{*}{$\begin{array}{l}\text { Organizational } \\
\text { Performance }\end{array}$} & \multirow{4}{*}{ Cost Reduction } & OPCR1 & 0.911 & 0.924 & Valid \\
\hline & & OPCR2 & 0.949 & 0.959 & Valid \\
\hline & & OPCR3 & 0.950 & 0.962 & Valid \\
\hline & & OPCR4 & 0.893 & 0.929 & Valid \\
\hline & \multirow{3}{*}{$\begin{array}{l}\text { Improved Customer Relations \& } \\
\text { Services }\end{array}$} & OPCRS1 & 0.899 & 0.898 & Valid \\
\hline & & OPCRS2 & 0.959 & 0.932 & Valid \\
\hline & & OPCRS3 & 0.896 & 0.914 & Valid \\
\hline & \multirow{3}{*}{$\begin{array}{l}\text { Improved Information } \\
\text { Accessibility }\end{array}$} & OPIA1 & 0.937 & 0.934 & Valid \\
\hline & & OPIA2 & 0.959 & 0.953 & Valid \\
\hline & & OPIA3 & 0.896 & 0,903 & Valid \\
\hline \multirow{3}{*}{ Interactivity } & & $\mathrm{I} 1$ & 0.949 & 0.942 & Valid \\
\hline & & $\mathrm{I} 2$ & 0.935 & 0.938 & Valid \\
\hline & & I3 & 0.883 & 0.883 & Valid \\
\hline \multirow{4}{*}{ Cost Effectiveness } & & CE1 & 0.743 & 0.675 & Valid \\
\hline & & CE2 & 0.883 & 0.893 & Valid \\
\hline & & CE3 & 0.892 & 0.864 & Valid \\
\hline & & CE4 & 0.719 & 0.820 & Valid \\
\hline
\end{tabular}

American Research Journal of Business and Management 
The Effect of Interactivity, Cost Effectiveness, and Compatibility on the Use of Social Media and its Implications for Organizational Performance

\begin{tabular}{|c|c|c|c|c|c|}
\hline \multirow{3}{*}{ Compatibility } & & C1 & 0.906 & 0.903 & Valid \\
\hline & & $\mathrm{C} 2$ & 0.949 & 0.939 & Valid \\
\hline & & C3 & 0.930 & 0.919 & Valid \\
\hline \multirow{11}{*}{ Social Media Usage } & \multirow{4}{*}{ SMU for Marketing } & SMM1 & 0.937 & 0.921 & Valid \\
\hline & & SMM2 & 0.907 & 0.913 & Valid \\
\hline & & SMM3 & 0.874 & 0.869 & Valid \\
\hline & & SMM4 & 0.945 & 0.921 & Valid \\
\hline & \multirow{4}{*}{$\begin{array}{l}\text { SMU for Customer service \& } \\
\text { relations }\end{array}$} & SMCRS1 & 0.897 & 0.887 & Valid \\
\hline & & SMCRS2 & 0.921 & 0.910 & Valid \\
\hline & & SMCRS3 & 0.936 & 0.929 & Valid \\
\hline & & SMCRS4 & 0.877 & 0.888 & Valid \\
\hline & \multirow{3}{*}{$\begin{array}{l}\text { SMU for Information } \\
\text { Accessibility }\end{array}$} & SMIA1 & 0.925 & 0.928 & Valid \\
\hline & & SMIA2 & 0.927 & 0.926 & Valid \\
\hline & & SMIA3 & 0.876 & 0.924 & Valid \\
\hline \multirow{9}{*}{$\begin{array}{l}\text { Entrepreneurial } \\
\text { Orientation }\end{array}$} & \multirow{3}{*}{ Proactiveness } & EOP1 & 0.871 & 0.862 & Valid \\
\hline & & EOP2 & 0.833 & 0.850 & Valid \\
\hline & & EOP3 & 0.787 & 0.760 & Valid \\
\hline & \multirow{3}{*}{ Risk Taking } & EORT1 & 0.779 & 0.806 & Valid \\
\hline & & EORT2 & 0.899 & 0.889 & Valid \\
\hline & & EORT3 & 0.869 & 0.846 & Valid \\
\hline & \multirow{3}{*}{ Innovativeness } & EOI1 & 0.930 & 0.927 & Valid \\
\hline & & EOI2 & 0.940 & 0.948 & Valid \\
\hline & & EOI3 & 0.849 & 0.880 & Valid \\
\hline
\end{tabular}

Source: Data Results with SPSS 23 (2018)

While reliability testing is related to the consistency, accuracy and predictability of a measuring instrument. Hair et.al. (2013) argue that the measurement of reliability ranges from 0 to 1 , where the lowest acceptable limit is 0.6 to 0.7 .

Table4. Reliability Test Results

\begin{tabular}{|c|c|c|c|c|}
\hline \multirow{2}{*}{ Variable } & \multirow{2}{*}{ Dimension } & \multicolumn{2}{|c|}{ Cronbach's Alpha } & \multirow{2}{*}{ Decision } \\
\hline & & Pre-test & Actual & \\
\hline \multirow{3}{*}{$\begin{array}{l}\text { Organizational } \\
\text { Performance }\end{array}$} & Cost Reduction & 0.943 & 0.958 & Reliable \\
\hline & Improved Customer Relations \& Services & 0.900 & 0.900 & Reliable \\
\hline & Improved Information Accessibility & 0.907 & 0.921 & Reliable \\
\hline Interactivity & & 0.911 & 0.910 & Reliable \\
\hline Cost Effectiveness & & 0.797 & 0.801 & Reliable \\
\hline Compatibility & & 0.920 & 0.910 & Reliable \\
\hline \multirow[t]{3}{*}{ Social Media Usage } & SMU for Marketing & 0.934 & 0.925 & Reliable \\
\hline & SMU for Customer Relations \& Services & 0.927 & 0.923 & Reliable \\
\hline & SMU for Information Accessibility & 0.890 & 0.917 & Reliable \\
\hline \multirow{3}{*}{$\begin{array}{l}\text { Entrepreneurial } \\
\text { Orientation }\end{array}$} & Proactiveness & 0.718 & 0.741 & Reliable \\
\hline & Risk Taking & 0.798 & 0.800 & Reliable \\
\hline & Innovativeness & 0.886 & 0.902 & Reliable \\
\hline
\end{tabular}

Source: Data Results with SPSS 23 (2018)

Before the assessment of the research hypothesis test, the data normality assessment is carried out first and the Goodness of Fit model is assessed.

American Research Journal of Business and Management 
The Effect of Interactivity, Cost Effectiveness, and Compatibility on the Use of Social Media and its Implications for Organizational Performance

Table5. Normality Test Results

\begin{tabular}{|c|c|c|c|c|c|c|}
\hline Variable & $\min$ & $\max$ & skew & c.r. & kurtosis & c.r. \\
\hline OPCR & -2.283 & 2.476 & .043 & .258 & -.539 & -1.631 \\
\hline OPCRS & -2.920 & 2.920 & -.028 & -.167 & -.108 & -.327 \\
\hline OPIA & -2.917 & 2.917 & .025 & .149 & -.267 & -.809 \\
\hline EOI & -2.484 & 2.108 & .031 & .187 & -.511 & -1.547 \\
\hline EORT & -2.356 & 2.892 & .115 & .698 & -.484 & -1.466 \\
\hline EOP & -2.925 & 2.925 & .012 & .071 & -.210 & -.636 \\
\hline SMM & -2.923 & 2.923 & -.027 & -.166 & -.153 & -.464 \\
\hline SMCRS & -2.917 & 2.917 & -.012 & -.070 & -.106 & -.322 \\
\hline SMIA & -2.918 & 2.918 & -.008 & -.050 & -.073 & -.220 \\
\hline
\end{tabular}

Source: Data Processed with AMOS 23 (2018)

In the results of testing for normality, the value of Critical Ratio (C.R) skewness and kurtosis from all dimensions shows that the results have no dimensions with a value of C.R outside of (-) 2.58 and (+) 2.58. Because the value of C.R located between -2.58 and 2.58 proves that the dimensions of the variable are normally distributed.

Table6. Goodness of Fit

\begin{tabular}{|c|c|c|c|c|}
\hline Types of Goodness of Fit & $\begin{array}{c}\text { Goodness of Fit } \\
\text { Measure }\end{array}$ & $\begin{array}{c}\text { Level of Acceptance } \\
\text { (Hair } \text { et al., 2013) }\end{array}$ & $\begin{array}{c}\text { Calculating } \\
\text { Measure }\end{array}$ & Acceptable \\
\hline Absolute & Chi-square & Small chi-square & 436.854 & Poor \\
Fit Measure & (df $=143)$ & \\
& $p$-value & $p$-value $\geq 0.05$ & 0.000 & Poor \\
& RMSE & $<0.10$ & 0.097 & Good fit \\
& RMR & $<0.10$ & 0.000 & Good fit \\
Incremental Fit Measure & NFI & $>0.90$ or close to 1 & 0.910 & Good fit \\
& TLI & $>0.90$ or close to 1 & 0.925 & Good fit \\
& CFI & $>0.90$ or close to 1 & 0.938 & Good fit \\
Parsimonious & IFI & $>0.90$ or close to 1 & 0.938 & Good fit \\
Fit Measure & AGFI & $>0.90$ or close to 1 & 0.770 & Acceptable Fit \\
& PNFI & $>0.90$ or close to 1 & 0.761 & Acceptable Fit \\
\hline
\end{tabular}

Source: The results of the questionnaire were processed with AMOS 23 (2018)

Hair et. al. (20103 states that from several testing criteria for Absolute Fit Measure, Incremental Fit Measure, and Parsimonious Fit Measure, if the results of one test are 'fit', it can be concluded that the model used is fit.

\section{RESUlts AND Discussion}

The model and results of SEM testing can be seen below:

Table 7. Hypothesis Testing Results

\begin{tabular}{|c|c|c|c|c|c|}
\hline & Hypothesis & Coefisien & C.R & $p$-value & Conclusion \\
\hline $\mathrm{H} 1$ & Interactivity positively influences social media usage. & 0.274 & 3.442 & 0.000 & Supported \\
\hline $\mathrm{H} 2$ & & & 2.992 & 003 & \\
\hline $\mathrm{H} 3$ & Compatibilitypositively influences social media usage. & 0.352 & 3.142 & 0.002 & Supported \\
\hline $\mathrm{H} 4$ & Social media usagepositively influences organizational performance. & 0.585 & 7.497 & 0.000 & Supported \\
\hline
\end{tabular}


The Effect of Interactivity, Cost Effectiveness, and Compatibility on the Use of Social Media and its Implications for Organizational Performance

\begin{tabular}{|c|c|c|c|c|c|}
\hline $\mathrm{H} 5$ & Social media usagepositively influences entrepreneurial orientation. & 0.921 & 20.553 & 0.000 & Supported \\
\hline $\mathrm{H} 6$ & $\begin{array}{c}\text { Entreprenuerial orientationpositively influences organizational } \\
\text { performance. }\end{array}$ & 0.432 & 5.783 & 0.000 & Supported \\
\hline
\end{tabular}

Source: Data Processed with AMOS 23 (2018)

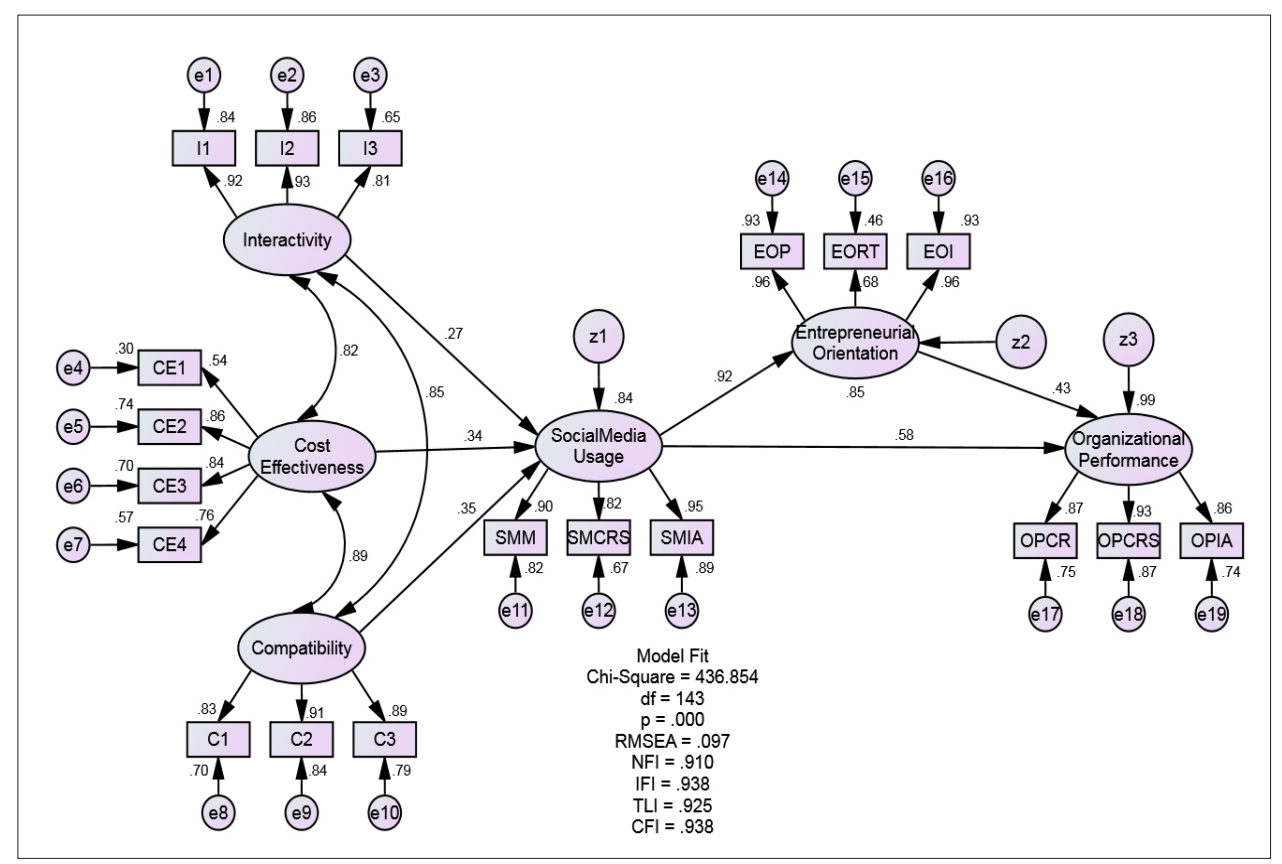

Fig2. Structural Equation Modeling (SEM) Standardized Estimates

In testing hypothesis 1 , the results of data processing show that Interactivity has an effect on social media usage, has a coefficient of 0.274 which means that the higher the perception of interactivity, the higher the perception of social media usage. The test results on the value of CR ( $t$-value) amounted to 3.442 greater than 1.96 or p-value of $0.000<0.05$ (alpha 5\%), it can be concluded statistically at the confidence level of $95 \%$ there is a positive effect of interactivity on social media usage . In testing hypothesis 2 , the results of data processing show that cost effectiveness affects social media usage, has a coefficient of 0.337 which means that the higher the perception of cost effectiveness, the higher the perception of social media usage. The test results on the value of CR (t-value) amounted to 2.992 greater than 1.96 or the p-value of $0.003<0.05$ (alpha 5\%), it can be concluded statistically at the $95 \%$ confidence level there is a positive effect of cost effectiveness on social media usage. In testing hypothesis 3 , the results of data processing show that compatibility affects social media usage, has a coefficient of 0.352 which means that the higher the perception of compatibility, the higher the perception of social media usage. The test results on the value of CR ( $\mathrm{t}$-value) is 3.142 greater than 1.96 or the p-value is $0.002<0.05$ (alpha 5\%), it can be concluded statistically at the $95 \%$ confidence level there is a positive influence on compatibility with social media usage.

In testing hypothesis 4 , the results of data processing show that social media usage has an effect on organizational performance, has a coefficient of 0.585 which means that the higher the perception of social media usage, the higher the perception of organizational performance. The test results on the value of CR (t-value) amounted to 7.497 greater than 1.96 or at the p-value of $0.000<0.05$ (alpha 5\%), it can be concluded statistically at the confidence level of $95 \%$ there is a positive influence on social media usage towards organizational performance. In testing hypothesis 5 , the results of data processing show that social media usage has an effect 
The Effect of Interactivity, Cost Effectiveness, and Compatibility on the Use of Social Media and its Implications for Organizational Performance

on entrepreneurial orientation, having a coefficient of 0.921 which means that the higher the perception of social media usage, the higher the perception of entrepreneurial orientation. The test results on the value of CR (t-value) amounted to 20,553 greater than 1.96 or at the p-value of $0.000<0.05$ (alpha 5\%), it can be concluded statistically at the confidence level of $95 \%$ there is a positive influence on social media usage towards entrepreneurial orientation.

In testing hypothesis 6 , the results of data processing show that entrepreneurial orientation affects organizational performance, has a coefficient of 0.432 which means that the higher the perception of entrepreneurial orientation, the higher the perception of organizational performance. The test results on the CR value ( $\mathrm{t}$-value) amounted to 5,783 greater than 1.96 or at the p-value of $0.000<0.05$ (alpha 5\%), it can be concluded statistically at the $95 \%$ confidence level there is a positive influence on entrepreneurial orientation organizational performance.

Then testing whether entrepreneurial orientation variables can mediate the influence of social media usage variables on organizational performance. The results obtained using the SOBEL test can be seen as below:

Table 8. Sobel Test

\begin{tabular}{|c|c|c|}
\hline Influence between Latent Variables & C.R & p-value \\
\hline $\begin{array}{c}\text { Social media usage } \rightarrow \text { organizational performancewith entrepreneurial orientation as a } \\
\text { mediating variable }\end{array}$ & 5.567 & 0.000 \\
\hline
\end{tabular}

Source: Results of processing with SOBEL test (2018)

Based on the results obtained it is known that entrepreneurial orientation mediates the influence of social media usage on organizational performance with a value of C.R ( $t$-value) of 5.567 (C.R> 1.96) or p-value of $0.000<0.05$ (alpha 5\%). The effect of mediating entrepreneurial orientation between social media usage and organizational performance is positive and significant. It means that the higher the perception of entrepreneurial orientation, the stronger the influence of social media usage on organizational performance.Also means that the perception of respondents is proactive, innovative and risk taking, further strengthening the company in using social media, which in turn can reduce costs, improve relationships and services to customers, and improve access to information whether it is information on new customers, old customers, or competitors.

\section{CONCLUSION}

Based on the results of the discussion of the research in the previous chapters, some conclusions can be drawn as follows: Interactivity has an effect on social media usage. The effect of interactivity on social media usage is positive and significant, with the most dominant element of Interactivity being in the element 'social media offers an interactive mechanism that creates added value for customers'. This shows that increasingly social media offers an interactive mechanism that will lead to increased social media usage. Cost effectiveness has an effect on social media usage. The effect of cost effectiveness on social media usage is positive and significant, with the most dominant element of cost effectiveness being the element 'social media increases branding'. This shows that the more social media can increase branding will lead to increased social media usage. Compatibility affects social media usage. The influence of compatibility on social media usage is positive and significant, with the most dominant compatibility element being the element of 'social media in accordance with hotel business operations'. This shows that the better the element of conformity/compatibility of social media with the operation of the hotel business will lead to increased social media usage. Social media usage has an effect on organizational performance.

The influence of social media usage on organizational performance is positive and significant, with the most dominant social media usage elements being on 'social media for information accessibility'. This shows that improving the use of social media, especially on social media for information accessibility will be able to improve organizational performance. Social media usage influences the entrepreneurial orientation. The influence 
The Effect of Interactivity, Cost Effectiveness, and Compatibility on the Use of Social Media and its Implications for Organizational Performance

of social media usage on entrepreneurial orientation is positive and significant, with the most dominant social media usage elements being on 'social media for information accessibility. This shows that improving the use of social media, especially on social media forinformation accessibility, will be able to improve the entrepreneurial orientation. Entrepreneurial orientation influences organizational performance. The effect of entrepreneurial orientation on organizational performance is positive and significant, with the dominant element of entrepreneurial orientation having 2 (two) elements, namely the elements of proactiveness and innovativeness. This shows that the improvement of entrepreneurial orientation especially the elements of proactiveness and innovativeness will result in increased organizational performance.

Entrepreneurial Orientation can mediate the influence of social media usage on organizational performance. This shows that increasingly the perception of respondents is proactive, innovative and risk taking, further strengthening the use of social media, which in turn will improve organizational performance through reduced marketing costs, increased relationship and service to customers, and increased access to information. Information on new customers, old customers or competitors.

\section{SUGGESTIONS FOR FURTHER RESEARCH}

Taking into account the various limitations of this study, researchers provide practical suggestions for further research including: further research not only to research in the hospitality industry, but in manufacturing industries or educational institutions. The variables studied regarding the use of social media are not only positive but also the negative side of using social media. It is necessary to consider adding qualitative research, to deepen conclusions obtained from the results of quantitative research, so that more comprehensive and indepth results are obtained. Further research is recommended to examine the online travel agent social media used by companies such as: traveloka, agoda, booking.com, tiket.com, bukalapak, and others.

\section{REFERENCES}

1. Anthony, R. N. M., \& Govindarajan, M.V. 2001. Management Control System. $10^{\text {th }}$ Edition, Chicago, Illinois: Richard D. Irwin, Inc.

2. Anderson, B. S., Covin, J. G., \& Slevin, D. P. 2009. Understanding the relationship between the entrepreneurial orientation and strategic learning: an empirical investigation. Strategic Entrepreneurship Journal, 3: 219-241.

3. Anshori, Y. 2010. Manajemen Strategi Hotel (Strategi Meningkatkan Inovasidan Kinerja). ITS Press.

4. Ainin, S., Parveen, F., Moghavvemi, S., \& Jaafar, N. I. 2015. Factor influencing the use of social media by SMEs and its performances measures. Journal of Industrial Management and Data Systems, 115(3): 570-588.

5. Alam, S.S., \& Noor, M. K. M. 2009. ICT adoption in small and medium enterprise and Empirical evidence of service sectors in Malaysia. International Journal of Business and Management, 4 (2): 112-125.

6. Agarwal, R., \& Venkatesh, V. 2002. Assessing a firm's Web Presence: a heuristic evaluation procedure for the measurement of usability. Information Systems Research, 13 (2): 168-168.

7. Adhi C., A. 2017. IniD aftar 24 BUMN yang Merugi. https://finance.detik.com/berita-ekonomi-bisnis/d3620207/ini-daftar-24-bumn-yang-merugidiuploadtanggal 24 Agustus 2017 (diaksestanggal 1 Agustus 2018).

8. Barney, J. B. 1991. Firm resources and sustained competitive advantage. Journal of Management, 17:99-120.

9. Baron, M.R., \& Kenny, A.D, 1986. The Moderator - Mediator Variable Distinction in Social: Psychological Research: Conceptual, Strategic, and Statistical Consideration. Journal Personality and Social Psychology, 5 (6): 1173-1182. 
The Effect of Interactivity, Cost Effectiveness, and Compatibility on the Use of Social Media and its Implications for Organizational Performance

10. BPS. 2016. Katalog Statistik Hotel danAkomodasi Lainnya di Indonesia. Katalog: 8403002.

11. Bennett, J. A. 2000. Mediator and Moderator Variables in Nursing Research: Conceptual and Statistical Differences. Research in Nursing \& Health, 23: 415-420

12. Belleghem, S.V., Eenhuizen, M., \&Veris, E. 2011. Social media around the world 2011. The Report by Insites Consulting.

13. Bovee, C, \& Thill, J. V. 2016. Business Communication Today (Thirteenth edition), Pearson.

14. Bolger, N., Shrout, P. E. 2002. Mediation in Experimental and Nonexperimental Studies: New Procedures and Recommendation. Psychological Methods, 7(4): 422-445.

15. Burton-Jones, \& Gallivan, M. J. 2007. Toward a deeper understanding of system usage in organizations: a multilevel perspective, MIS Quaterly, 31(4): 657-679.

16. Bhuian, S. N., Mengue, B., \& Bell, S. J. 2005. Just entrepreneurial enough: the moderating effect of entrepreneurship on the relationship between market orientation and performance. Journal of Business Research, 58: 9-17.

17. Chan, Y. 2000. IT value the great devide between qualitative and quantitative individual and organizational measures. Journal of Management Information Systems, 16(4): 225-261.

18. Cooper, D. R,.\& Emory, W. C. 1995. Business Research Methods, Boston: Irwin.

19. Cooper, D. R., \& Schindler, P. S. 2014. Business Research Methods (12 ${ }^{\text {th }}$ edition) New York: McGraw-Hill.

20. Cone. 2008. Business in social media study. http://onesocialmedia.com/wp-content/uploads/2010/03/ 2008_business_in_social_media_fact_sheet.pdf (diaksestanggal 14 Desember 2015).

21. Covin J. G., \& Slevin, D. P. 1989. Strategic management of small firms in hostile and benign environments. Strategic Management Journal, 10:75-87.

22. Chong, A. Y. L., \& Chan, F. T. 2012. Structural equation model for multi-stage analysis on radio frequency identification (RFII) diffusion in the health care industry. Expert Systems with Applications, 39(10): 86458654.

23. Colton, D. A., Roth, M. S., \& Bearden, W. O. 2010. Drivers of international e-tail performance the complexities of orientation and resources. Journal of International Marketing, 18(1): 1-22.

24. Covin, J.G., \& Slevin, D. P. 1991. A Conceptual model of entrepreneurship as firm behaviour. Entrepreneurship: Theory and Practices, 16: 7-25

25. DeLone, W. H. \& McLean, E. R. 2003. The DeLone and McLean model of information systems success a ten year update. Journal of Management Information Systems, 19(4): 9-30.

26. Derham, R., Cragg, P., \& Morrish, S. 2011. Creating value an SME and social media. PACIS 2011 Proceedings, Paper 53. http://aiselaisnet.org/pacis 2011/53

27. Dizon, T., Thompson, B., \& McAllister, P. 2002. The value of ICT for SMEs in the UK: a critical literature review, report for small business service research programme. The College of Estate Management, West Berkshire, www.sbs.gov.uk/SBS_Gov_files/researchandstats/value_of_ICT_for_SMEs_UK,pdf.

28. Elliot, R., \& Boshoff, C. 2005. The influence of organisational factors in small tourism businesses on the success of internet marketing. Management Dynamics, 14(3): 44-58. 
The Effect of Interactivity, Cost Effectiveness, and Compatibility on the Use of Social Media and its Implications for Organizational Performance

29. Elaluf-Calderwood, S., Kietzmann, J., \&Saccol, A. Z. 2005. Methodological approach for mobile studies: empirical research considerations. $4^{\text {th }}$ European Conference on Research Methodology for Business and Management Studies, Academic Conferences Limited, Paris, 133-140.

30. Edward, DJ. 2017. IniPenyebabKerugian 24 BUMN? https://nusantara.news/ini- penyebab-kerugian-24bumn/diuploadtanggal 8 September 2017 (diaksestanggal 1 Agustus 2018).

31. Ferdinand, A. 2002. Structural Equation Modellingdalam Penelititan Manajemen. Badan Penerbit UNDIP, Semarang.

32. Fisher, T. 2009. ROI in social media: a look at the argumemts. Journal of Database Marketing and Customer Strategy Management, 16 (3): 189-195.

33. Fuhl, F. 2006. TheInfluence Factors of Dynamic Capabilities: The Case of InnovationSpeed at Korean Electronics Companies. Dissertation of Doctor of Business Administration of the University of St.Gallen,Druckerei Lauterberg, Ketzin.

34. Gray, B. J., Matear, S., \& Matheson, P. K. 2002. Improving service firm performance. Journal of Service Marketing, 16(3): 186-200.

35. Ghozali, Imam danFuad. 2014. Structural Equation Modelling, Teori, Konsep, danAplikasidengan Program Lisrell 9.10. Edisi 4, Semarang: BP-UNDIP.

36. Goldfarb, A., \& Tucker, C. 2011. Online display advertising: targeting and obtrusibveness. Marketing Sciences, 30 (3): 389-404.

37. Ha, L., \& James, A. L. 1998. Interactivity reexamined: a baseline analysis of early business websites. Journal of Broadcasting and Electronic Media, 42 94): 457-474.

38. Hair, J. F., Anderson, R. E., \& Black, W. C. 2013. Multivariate Data Analysis, Upper Saddle River, New Jersey: Prentice Hall Inc.

39. Harris, A. L., \& Rea, A. 2009. Web 2.0 and virtual world technologies. Journal of IS Education, Vol. 20 (2): 137-144.

40. Hariandja, M. T. E. 2004. ManajemenSumberDayaManusia, Pengadaan, Pengembangan, Pengkompensasian, dan Peningkatan Produktivitas Pegawai. PT. Grasindo, Jakarta.

41. Hayes A.F.(2009). Beyond Baron and Kenny: Statistical Mediation analysis In The Millennium. Communication Monograph, 76(4): 408-420

42. Hsu, C., Lu, H., \&Hsy, H. 2007. Adoption of the mobile internet: an empirical study of multimedia message services (MMS), The International Journal of Management Science, 35 (6): 715-726.

43. Hudson, M. 2017. What is social media.https://www.thebalancesmb.com/what-is-social-media-2890301 di upload tanggal 25 September 2017 (diaksestanggal 27 April 2018).

44. Immorlica, N., Kleinberg, J., Mahdian, M., \& Wexler, T. 2007. The role of compatibility in the diffusion of technologies through social networks. http://www.cs.cornell.edu/Info/People/kleinber/ec07-compat.pdf (diaksestanggal 28 April 2018).

45. Jiang, Z., \& Benbasat, I. 2007. Investigating the influence of the functional mechanisms of online product presentations. Information Systems Research, 18 (4): 454-470.

46. Kaplan, A. M., \&Haenlein, M. 2010. Users of the world, unite! the challenges and opportunities of social media. Business Horisons, 53 (1): 59-68.

American Research Journal of Business and Management

Page 14 
The Effect of Interactivity, Cost Effectiveness, and Compatibility on the Use of Social Media and its Implications for Organizational Performance

47. Kern, S. A. 2010. Why A solid social media strategy is a cost-effective marketing tool. http://www.faceitsocial media.com/2010/08/why-social-media-is-a-cost-effective-marketing-tool/ (diaksestanggal 28 April 2018).

48. Kietzmann, J. H., Silvestre, B. S., McCharty, L. P, \& Pitt, L. F. 2012. Unpacking the social media phenomenon: towards a research agenda. Journal of Public Affair, 12 (2): 109.119.

49. Kim, A. J., \& Ko, E. 2012. Do social media marketing activities enhance customer equity? an empirical study of luxury fashion brand. Journal of Business Research, 65(10): 1480-1486.

50. Khumaedy, M. Arief. 2017. http://setkab.go.id/tahun-2017-kita-genjot-sektor-pariwisata/ (diaksespada tanggal 4 Januari 2018).

51. Lee, Y., \& Kozar, K. 2002. Developing a theory of website usability: an exploratory study to identity constructs and nomological networks. Decision Support Systems, 52 (2): 450-463.

52. Leonardus, R. R. 2015. Keuntungan Kompetitif Organisasidalam Perspektif Resources Based View. ASE, 11 (5): $1-12$.

53. Li, H., Daugherty, \& Biocca, F. 2002. Impact on 3-D advertising on product knowledge brand attitude, and purchase intentions: the mediating role of presence. Journal of Advertising, 31 (3): 43-57.

54. Liu, Y., \& Shrum, L. J. 2002. What is in interactivity and is it always such a good thing? implications of definition, person, and situation for the influence of interactivity on advertising effectiveness. Journal of Advertising, 31 (4): 53-64.

55. Lim, S., \& Palacios-Marques, D. 2011. Culture and purpose of web 2.0 service adoption: a study in the USA, Korea and Spain. The Service Industries Journal, 31(1): 123-131.

56. Lovejoy, K, Waters, R. D., \& Saxton, G. D. 2012. Engaging Stakeholders through Twitter: How Non Profit Organizations are Getting More Out 140 Characters or Less. Public Relations Review, 38 (2): 313-318.

57. Low, C., Chen, Y., \& Wu, M. 2011. Understanding the determinants of cloud computing adoption. Industrial Management \& Data Systems, 111 (7): 1006-1023.

58. Lumpkin, G.T., \&Dess, G.G. 1996, Clarifying the entrepreneurial orientation construct and linking it to performance, Academy of Management Review, 21(1): 135-172.

59. Manzano, J. A., Kuster, I., \& Vila, N. 2005. Market orientation and innovation: an inter-relationship analysis. European Journal of Innovation Management, 8(4): 437-452.

60. Matuszak, G. 2007. Enterprise 2.0: Fad or future? the business role for social software platforms: KPMG. available at: www.kpmg.ca/en/industries/ice/documents/thebusinessroleforsocialsoftwareplatforms. pdf.

61. Mavondo, F. T., Chimhanzi, J., \& Stewart, J. 2005. Learning orientation and market orientation: relationship with innovation, human resources practice and performance. European Journal of Marketing, 39 (11): $1235-1263$

62. Michaelidou, N., Siamagka, N. T., \& Christodoulides, G. 2011. Usage, barriers and measurement of social media marketing an exploratory investigation of small and medium B2B brands. Industrial Marketing Management, 40 (7): 1153-1159.

63. Mostafa, R. H., Wheeler, C., \& Jones, M. 2006. Entrepreneurial orientation, commitment to the internet and export performance in small and medium sized exporting firms. Journal of International Entrepreneurship, 3(4): 291-302.

American Research Journal of Business and Management Page 15 
The Effect of Interactivity, Cost Effectiveness, and Compatibility on the Use of Social Media and its Implications for Organizational Performance

64. Miller, D. 1983. The correlates of entrepreneurhips in three types of firms. Management Science, 29: 770-790.

65. Muller, D., Judd, C. M., Yzerbyt, V.Y. 2005. When Moderator is Mediated and Mediation is Moderated. Journal of Personality and Social Psychology, 89(6): 852-863.

66. Noe, Raymond A. 2017. Employee Training and Development, Seventh Edition, New York: McGraw-Hill Education.

67. Olivares, A. M., \& Lado, N. 2003. Market orientation and business economic performance: a mediated model. International Journal of Service Industry Management, 14(3): 2847-309.

68. Odoom, R., Anning-Darson, T., \&Acheampong, G. 2017. Antecendents of social media usage and performance benefits in small- and medium-sized enterprise (SMEs). Journal of Enterprise Information Managament, 30 (3): 383-399.

69. Parveen, F., Jaafar, N. I., \&Ainin, S. 2016. Social media's impact on organizational performance and entrepreneurial orientation in organizations. Management Decision, 54 (9): 2208-2234.

70. Preacher, K.J., Rucker, D. D., \&Hayes, A. F. 2007. Addresing Moderated Mediation Hypotheses: Theory, Method and Prescriptions. Multivariate Behavioral Resaarch, 42(1): 185-227.

71. Preacher, K.J., Lakowich, M.J., \& Kelley, K. 2017. A Novel Measure of Effect Size for Mediation Analysis. American Psychological Association, http://dx.doi.org/10/1037/met.0000165

72. Pride, W., Hudges, R. J., \& Kapoor, J. R. 2017. Foundation of Business (Fifth edition), Cengage Learning.

73. Quan-Haase, A., \& Young, A. L. 2010. Uses of gratifications of social media: a comparison of facebook and instant messaging. Bulletin of Science, Technology and Society, 30 (5), 350-361.

74. Ramdani, B., Kawalek, P., \& Lorenzo, O. 2009. Predicting SMEs adoption of enterprise systems. Journal of Enterprise Information Management, 22 (1-2): 10-24.

75. Rothaermel, F. T. 2012. Strategic Management: Concepts and Cases. McGraw-Hill/Irwin, p. 5.

76. Rose, M.B., Holmbeck, G.N., Coakley, R.M, Franks, R.A. 2004. Mediator and Moderator Effect in Developmental and Behavioral Pediatric Research. Developmental and Behavioral Pediatrics, 25(1): 58-67.

77. Samuel, K., 2017. Cost-Effective Versus Low-Value Ways To Advertise Through Social Media. Available at: https://www.forbes.com/sites/forbesagencycouncil/2017/05/22/cost-effective-versus-low-value-waysto-advertise-through-social-media/2/\# (diaksestanggal 28 April 2018).

78. Saffer, A. J., Sommerfeldt, E. J., \& Taylor, M. 2013. The effect of organizational twitter interactivity on organization-public relationship. Public Relation Review, 39 (3): 213-215.

79. Sekaran, U., \& Bougie, R. 2013. Research Methods for Business (6 ${ }^{\text {th }}$ edition). West Sussex: John Wiley \& Sons Ltd.

80. Sundar, S. S., Kalyanaraman, S., \& Brown, J. 2003. Explicating website interactivity impression formation effects in political campaign sites, Communication Research, 30 (1), 30-59.

81. Shuai, J. J., \& Wu, W. W. 2011. Evaluating the influences of e-marketing on hotel performance by DEA and Grey Entrophy. Expert Systems with Applications, 38(7): 8763-8769.

82. Shah, A., Hashmi, H.S., Chishti, F.A., 2013. Must Has Changed since Baron and Kenny's (1986) Classic Paper: Let us Learn What Kenny's (2012) Contemporary Mediation Analysis Prescribes. Jinnah Business Research Centre, 1 (1): 58-67.

American Research Journal of Business and Management

Page 16 
The Effect of Interactivity, Cost Effectiveness, and Compatibility on the Use of Social Media and its Implications for Organizational Performance

83. Sugiyono. 2013. Metode Penelitian Bisnis. Cetakan Kesepuluh, Penerbit CV. Alfabeta, Bandung.

84. Sudan, S. J., \& Sharma, B. R. 2015. Learning strategic orientation for enhancing business performance. International Journal of Knowledge Management, 3(1): 27-32.

85. Suliantha, F. 2015. Keajaiban Sosial Media: Fantastis Menumbuhkan Visitor, Circle, Lines, Koneksi, Retweet, dan Follower, Kompas Gramedia: PT. Elex Media Komputindo, Jakarta

86. Steizner, M. A. 2014. Social Media Marketing Industry Report. The Social Media Examiner website at www. socialmediaexaminer.com (diaksestanggal 27 Februari 2015)

87. Tan, K.S., Chong, S. C., Lin, B., \& Eze, U. C. 2009. Internet-based ICT adoption: evidence from Malaysian SMEs, Industrial Management and Data Systems, 109 (2): 224-244.

88. Tika, P. M. 2014. Budaya Organisasidan Peningkatan Kinerja Perusahaan, Bumi Aksara, Jakarta.

89. Wang, Y. M., Wang, Y. S., \& Yang, Y. F. 2010. Understanding determination of RFID adoption in the manufacturing industry. Technological Forecasting and Social Change, 77 (5): 803-815.

90. Wang, T., Thornhill, S., \& De Castro, J. O. 2017. Entrepreneurial orientation, legitimation, and new venture performance. Strategic Entrepreneurship Journal, D0I:10.1002/sej.1246.

91. Weinberg, B. D., \& Pehlivan, E. 2011. Social spending: managing the social media mix. Business Horizons, 54 (3): $275-282$.

92. Williamson, D. A. 2011. Worldwide Social Network and Spending a Rising Tide. www.emarketer.com/Report. aspx?code=emarketer_200692

93. Wiklund, J. 1999. The sustainability of the entrepreneurial orientation-performance relationship. Entrepreneur Theory and Practice, 24(1): 37-48.

94. Wiklund, J., \& Shepherd, D. 2003. Knowlwdge based resources, entrepreneurial orientation, and the Performance of small and medium sized business. Strategic Management Journal, 24: 1307-1314.

95. Wiklund, J., \& Shepherd, D. 2005. Entrepreneurial orientation and small business performance: a configurational approach. Journal of Business Venturing, 20: 71-91.

96. Wijanto, S. H. 2008. Structural Equation Modelling dengan Lisrel 8.8. edisipertama: Yogyakarta, Grahallmu.

97. Zappe, J. 2010. The ROI of Social Media. Journal of Corporate Recruiting Leadership, 5 (3): 3-9

Citation: B Medina Nilasari, Farida Jasfar, Agustinus Sri Wahyudi. "The Effect of Interactivity, Cost Effectiveness, and Compatibility on the Use of Social Media and its Implications for Organizational Performance" American Research Journal of Business and Management. 2019; 5(1): 1-17.

Copyright (c) 2019 B Medina Nilasari, Farida Jasfar, Agustinus Sri Wahyudi. This is an open access article distributed under the Creative Commons Attribution License, which permits unrestricted use, distribution, and reproduction in any medium, provided the original work is properly cited.

American Research Journal of Business and Management

Page 17 